\title{
JUHOK, GAZDÁK, KÖNYVEK, ÚJSÁGOK ÉS TÁRSASÁGOK: A GENETIKA SZÜLETÉSÉRŐL, MÁSKÉPP
}

A kőszegi Felsőbbfokú Tanulmányok Intézetének új, Beszélö Házak címú, Miszlivetz Ferenc-szerkesztette sorozata egy olyan kötetpárral debütált, amelynek egyike teljes egészében Festetics Imre gróf (1764-1847) és kortársai szerepét igyekszik közelebb hozni az olvasóhoz, amelyet a genetika tudományának kialakulásban játszottak. (A másik kötet, a Köszegi történetek egyik fejezete pedig Söptei Imrének és Mátay Mónikának köszönhetően Festetics Imre kőszegi életének epizódjaiba enged betekintést, korabeli forrásanyag alapján.)

A „Festetics-rejtélyben” a szerző, Poczai Péter két kérdésre keresi a választ. Miképp hullhatott ki a genetika históriájából Festeticsnek és a helyi Mezőgazdasági Társaság szekciójaként müködő Brünni Juhos Társaságnak az emlékezete, ami miatt a mai napig Gregor Mendellel kezdődnek a tudománytörténeti áttekintések, s miként lehetne egészen pontosan kijelölni Festetics és a társaság helyét a szellemi kölcsönhatások kronológiai labirintusában, megkönnyítve mindazok dolgát, akik a friss felfedezéseket a jövő immár kiegészített rendszerezéseibe kívánják beépíteni.

Azt mindenekelött kétségkívül érdekesnek és talán szokatlannak is kell minősítenünk, hogy mind Festetics, mind a ma már a biotechnológia atyjának tekintett Ereky Károly (1878-1952) jelentőségére is külföldi kutatók hívták fel a figyelmet a nyolcvanas években. (Festetics esetében Vítězslav Orel és Robert J. Wood, Erekynél Robert Bud.) Utána persze megélénkült a hazai figyelem, és ma már sokan tekintik feladatuknak, hogy újabb és újabb adalékokkal gazdagítsák a képet.

Poczai könyve több ponton is nagy előrelépésnek tekinthető a még mindig csak kibontakozófélben lévő diskurzusban. A Festetics-jelenséget a genetikatörténeti előzményekhez igazítva bontja ki, részletesen bemutatja annak a hálózatnak a tagjait (Christian Carl André, Salm gróf, Ehrenfels báró), akikkel szoros együttműködésben, állandó szakmai egyeztetések, viták, terminológiai és módszertani próbálkozások kereszttüzében fejlesztette és formulázta a nézeteit. Pontosan listázza, mi is az, amiben Festetics elsősége és jelentősége vitathatatlanul megnyilvánul, a genetika terminus első használatától a később mendeliként azonosított törvények némelyikének egészen pontos megfogalmazásáig. Jelentősen bővíti az elemzésekbe bevonható szöveghagyományt Festetics magyarra elsőként lefordított vitacikke, levele, eddig nem ismert források és titkosszolgálati jelentések felhasználásával. Poczai összeállította a német nyelvű Festetics-cikkek bővítésre váró indulólistáját is, világossá téve, hogy még sok lappangó szöveg lehet, és komoly feladatok várnak a Festetics-filológiára. Ennek a programnak a létjogosult- 
ságát mi sem bizonyítja jobban, mint hogy az eddigi legterjedelmesebb összegzésből mennyi mindent hiányolhatunk még.

Festetics gazdálkodói és gondolkodói gyökereinek forrásvidékén most csak a grófi család csodálatos keszthelyi könyvtára szerepel, amely a korabeli agrár-szakirodalom javát tartalmazta. De nem jelenik meg kellő súllyal például Kisszántói Pethe Ferenc (1763-1832), akinek rövid életü magyar nyelvű gazdasági lapja, a Vizsgálódó Magyar Gazda már címében is azt az igényt testesítette meg, hogy a gyakorló szakemberek közeledjenek a természetvizsgálókhoz, vértezzék fel magukat az empíria és az absztrakció fegyverével (amit majd a Brünni Juhos Társaság és testvérszervezete, a Természettudományos Társaság emel még magasabb szintre azzal, hogy a tudomány képviselőit igyekszik a „terepre” csábítani). Lapja csődje után Pethe öt évig (1797-től 1801-ig) a Georgikon egyik motorja. Szervez, tanít, és a tangazdaságot irányítja. S noha Festetics csak 1803tól fog juhtenyésztésbe, kapcsolatuk bizonyára meghatározó jelentőségü - $\mathrm{s}$ talán nem véletlen, hogy 1815-ben Festetics Pethe új lapjában, a Nemzeti Gazdában tesz közzé felhívást hazai társaság létrehozására. A „Vasi Juhtenyésztő Társaságról” (1815-1820) megtudjuk, hogy a kontinens második állatnemesítő szervezete volt, épp annyit, hogy ennél sokkal részletesebb ismeretekre vágyjunk most már a müködéséről, tagjairól, hatásáról, megszűnése okairól. S hasonlóképpen a gazdálkodó Festetics juhok között töltött mindennapjairól, közvetlen munkatársairól, állománylistáiról, bundavastagság-mérő eszközének innovációtörténetéről, Chernel Dáviddal és másokkal való kapcsolatáról.

Ami magát az elfeledettséget illeti, kevés megfejtésre váró mozzanat maradt. De azt is mondhatnánk, nem nagyon van itt „rejtély”, ami nyomozómunkát kíván. Hogyan is teremtődhetett volna magától reflektív folytonosság, ha a juhtenyésztők -Jean-Baptiste Lamarck és Charles Darwin elött - nem lehettek tisztában azzal, hogy egy tudományág megszületésénél bábáskodnak, amely haláluk után sok évtizeddel szökken majd csak szárba - s miért akartak volna sok generációval később, az immár laboratóriumok zárt falai között folyó tudományos akadályverseny szereplöi „ősatyákat” keresve a kutatástörténeti régmúltban tallózgatni, amikor számukra a közeljövő és a közelmúlt jelentette az igazi kihívást? Mindenekelőtt és elsősorban a tudományos presztízst és a szabadalmi joggal lefedett megtérülést biztosító elsőségi kérdések magukhoz vonzása.

Amikorra pedig már tudománytörténeti kutatások feladata lett volna az előtörténet tisztázása, nagyjából a huszadik század hatvanas éveitől, akkor nem Trofim Liszenko áltudományos árnyéka, hanem alapvető szemléleti és infrastrukturális akadályok torlaszolták el az utat a juhtenyésztő gazdák jelentőségének felismeréséhez. Az 1884-ben elhunyt Mendel újrafelfedezése már a huszadik század legelején bekerült a kánonba, két évtized szenvedélyes vitái után, egyfajta kezdőpontként. Onnantól azonban miért is lett volna igény arra, hogy a brünni szerzetes előtti időkben kutakodjon valaki további előzményekért, amikor az uralkodó 
történetszemléleti nézőpont épp nagy emberek, nagy hadvezérek, nagy lángelmék és nagy felfedezők kronológiai gyöngysorokra való felfüzésével operált, s Mendellel sikerült a panoptikum első darabját megnyugtatóan elhelyezni? Több mint érdekes, hogy Vannevar Bush, akinek 1945-ös esszéjét tekintik az internet megszületéséhez vezető gondolkodástörténeti alapkőletételnek, épp (a nála: osztrák szerzetesként említett) a Mendel 1865-ös közleményét követő harmincéves visszhangtalan csenddel illusztrálja egy későbbi írásában, miért is olyan fontos az, hogy a releváns szakmai információk könnyü és gyors elérése előtt álló akadályokat megszüntessük.

S végül: a molekuláris biológiai tudáscsere nemzetköziesedése is csak 1930-tól tünik érdemesnek a tárgyalásba vonásra, miért ment volna vissza bárki még száz évet az időben, korábbi tudáscsereformákat és áramlásrendszereket vizslatva?

Amikorra pedig a „nagy emberek” nézőpontját felváltó hálózati szemlélet, a beágyazottságok és hatáskapcsolatok szociologizáló vizsgálatára épülő komplex megközelítések már igényelték volna a nagyobb felbontású históriai rekonstrukciót, a nehézséget egy ideig még a forrásanyagokhoz való eljutás jelentette. A releváns információdarabkák ugyanis úgy lappangtak levéltárakban, kézirattárakban, kis példányszámban megjelent értesítőkben, jegyzőkönyvekben, folyóiratokban, hogy még metaadatok sem segíthették a hozzájuk való eljutást: kevés esélyt kap a véletlen, ha a kutatók nem tudják, hogy mit keressenek és kereshetnek. A kulturális örökség digitalizálásának újabb és újabb hullámai azonban egyre kisebb gyüjtemények egyre kisebb jelentőségünek vélt állományaihoz is elértek, így amikor az első, Mendel elé pillantó kutatási kérdés találkozni tudott az első releváns forrással, onnantól kezdve a diskurzus megteremtődött, s immár irányítottan lehetett folytatni, egyre kedvezőbb feltételek között az adatgyüjtést. Ennek az útnak egy fontos megállója a könyv, amelynek érdemei sorához illesszük még Szathmáry Eörs kiváló, további elmélyedésre inspiráló előszavát, az igényes és színvonalas kivitelezést és a borító szépségét.

Nem mehetünk azonban el szó nélkül amellett, hogy némi szerkesztői munka még ráfért volna a szövegre, hogy egységesebb, feszesebb, következetesebb rendben, kevesebb önismétléssel tárhassa elö a mondanivalóját.

(Poczai Péter: A Festetics-rejtély. A genetika története és Festetics Imre hagyatéka. Köszeg: Felsőbbfokú Tanulmányok Intézete, 2019, 159 o.)

Z. Karvalics László 